Meisi Kurniasari, Rahmadani Yusran/Peningkatan Peranan Sosial Masyarakat dalam Pengembangan Wisata Hot Water Boom Sapan Maluluang di Nagari Pauh Duo Nan Batigo Kecamatan Pauh Duo Kabupaten Solok-Selatan

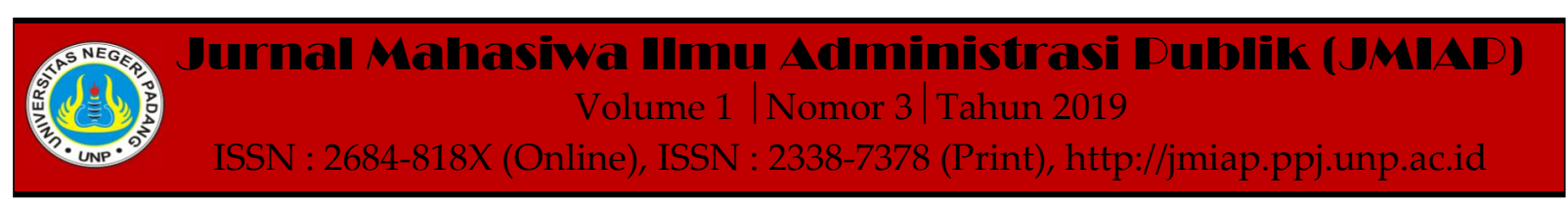

\title{
PENINGKATAN PERANAN SOSIAL MASYARAKAT DALAM PENGEMBANGAN WISATA HOT WATER BOOM SAPAN MALULUANG DI NAGARI PAUH DUO NAN BATIGO KECAMATAN PAUH DUO KABUPATEN SOLOK-SELATAN
}

\author{
Meisi Kurniasari ${ }^{1(a)}$, Rahmadani Yusran ${ }^{2(b)}$ \\ ${ }^{1}$ Jurusan Ilmu Administrasi Negara, Universitas Negeri Padang \\ ${ }^{2}$ Jurusan Ilmu Administrasi Negara, Universitas Negeri Padang \\ a)meisikurniasari07@gmail.com, b)yusranrdy@fis.unp.ac.id
}

\begin{abstract}
This study aims to analyze the increasing social role of the community in the development of HWB attractions. This research uses a qualitative approach with descriptive methods. The informants of this study were determined by purposive sampling technique, including the general subdivision and staffing of the department of tourism and culture Kabupaten Solok Selatan, Wali Nagari Youth Chairperson, Community Leaders in Nagari Pauh Duo Nan Batigo Pauh Duo District Kabupaten Solok Selatan, officers, visitors, and the community around HWB attractions. techniques collection techniques carried out by observation, interview and study documentation. To test the validity of the data using source triangulation techniques. The results of this study indicate that forms of social role in developing HWB attractions provide information to the government, increase people's willingness to accept decisions, and democratize decision making. During this time, the role of the government in involving the social role of the community in the development of HWB attractions is still limited. This shows that there is no government goodwill involving the social role of the community in the development of HWB attractions. Furthermore, the supporting factors for increasing the social role of the community in developing $H W B$ attractions are the community involved in planning $H W B$ attractions, the willingness of the community to support the implementation of regulations made in the framework of developing HWB attractions, the involvement of the community in supporting the potential of existing tourist attractions area. While the inhibiting factor is the lack of local community initiative in managing tourist facilities, there is no permanent work for the surrounding community in HWB tourism objects. This study concludes that increasing the social role of the community in developing $H W B$ attractions needs to be done in actively involving the social role of the community. In addition, the role of the government in involving the social role of the community is still limited, because there is no seriousness from the government in involving the social role of the community as a whole in the development of HWB tourism objects.
\end{abstract}

Keywords : Social Role of the Community, Tourism Development

Corresponding author. Email.meisikurniasari07@gmail.com,yusranrdy@fis.unp.ac.id

How to cite this article. Kurniasari. M \& Yusran. R. (2019). Peningkatan Peranan Sosial Masyarakat dalam Pengembangan Wisata Hot Water Boom Sapan Maluluang di Nagari Pauh Duo Nan Batigo Kecamatan Pauh Duo Kabupaten Solok-Selatan. Jurnal Mahasiwa Ilmu Administrasi Publik (JMIAP) Jurusan Ilmu Administrasi Negara Fakultas Ilmu Sosial Universitas Negeri Padang, Volume 1 (3), Hal. 99-108

http://jmiap.ppj.unp.ac.id

ISSN : 2684-818X (Online), ISSN : 2338-7378 (Print)

Copyright(C2019. Published by Pusat Kajian-Pemberdayaan dan Pelayanan Masyarakat (PK-P2M) FIS UNP Padang 
Meisi Kurniasari, Rahmadani Yusran/Peningkatan Peranan Sosial Masyarakat dalam Pengembangan Wisata Hot Water Boom Sapan Maluluang di Nagari Pauh Duo Nan Batigo Kecamatan Pauh Duo Kabupaten Solok-Selatan

\section{PENDAHULUAN}

Ada begitu banyak agenda pemberdayaan yang harus dilakukan oleh pemerintah seperti pemberdayaan politik, pemberdayaan ekonomi, pemberdayaan sosial budaya, pemberdayaan bidang kesehatan, pemberdayaan lingkungan, pemberdayaan bidang pendidikan dan lain sebagainya. Rasanya mustahil jika semua agenda atau program pemberdayaan tersebut dapat dilaksanakan oleh pemerintah sendiri. Selain alasan kompleksitas program, alasan utama lainnya adalah karena ada dua fungsi pokok pemerintah lainnya yang mesti diprioritaskan yaitu fungsi pelayanan dan fungsi pembangunan.

Oleh karena itu menjadi sebuah keniscayaan bagi pemerintah untuk dapat berbagi fungsi agar program-program pemerintah yang volumenya cukup besar tersebut menjadi berkurang. Kondisi seperti inilah dibutuhkan sebuah badan selain pemerintah yang dapat mencurahkan segala perhatian dan dayanya untuk kegiatankegiatan kemasyarakatan. Maka, keberadaan organisasi kemasyarakatan yang nota bene sebuah organisasi yang bekerja untuk masyarakat dianggap paling relevan untuk menjadi agen pemerintah dalam menjalankan fungsi pemerintah bidang pemberdayaan.(Adil Mubarak, 2014).

Peningkatan peranan sosial mayarakat dalam pengembangan obyek wisata perlu dilakukan. Hal ini disebabkan karena belum adanya goodwill pemerintah dalam melibatkan peran sosial masyarakat dalam perencanaan, pembangunan, dan pengembilan keputusan. Selain itu, terlihat belum banyak masyarakat yang mendukung pengembangan pariwisata dalam bentuk sadar wisata, daya tarik wisata, dan belum adanya partisipasi masyarakat dalam pengembangan objek wisata HWB. Pada dasarnya Pengembangan wisata di hot water boom membutuhkan peranan masyarakat secara aktif seperti pemahaman tentang strategi yang dilakukan serta dukungan yang dilakukan dalam pengembangan seperti ikut serta dalam proses perencanaan, proses pembangunan dan lain sebagainya. Tanpa peranan aktif dari masyarakat pengembangan tidak akan berjalan dengan optimal.

Di kabupaten Solok-Selatan pengembangan pariwisata sudah dilaksanakan sejak tahun 2004. Pasca pemekaran Kabupaten Solok-Selatan menjadi daerah yang otonom, pembangunan sarana dan prasarana termasuk pariwisata masih tertinggal di bandingkan daerah lainnya di Sumatera Barat (Yusran, 2007). Namun demikian pada tahap awal pengembangan pariwisata dalam rencana tata ruang wilayah daerah Kabupaten Solok Selatan th 2012-2032 telah ditetapkan dalam Perda Kabupaten Solok Selatan No. 8 Th 2012, pada pasal 4 strategi pengembangan kawasan budidaya melalui optimalisasi fungsi kawasan dalam mendorong pertumbuhan ekonomi dan kesejahteraan masyarakat sebagaimana yang dimaksud pada pasal 3 huruf c pada bagian (i) pengembangan kawasan dan objek pariwisata dikembangkan melalui objek wisata andalan dalam peningkatan promosi yang dikaitkan melalui kalender wisata melalui skala nasional, penyediaan sarana dan prasarana wisata, dan pelestarian kawasan potensi wisata serta perlindungan budaya penunjang pariwisata.

Pengembangan pariwisata di Wisata Hot Water Boom Sapan Maluluang. Pengembangan pariwisata di daerah ini belum optimal dalam meningkatkan peran sosial masyarakat. Hal ini, terlihat dari belum banyaknya masyarakat yang mendukung pengembangan pariwisata dalam bentuk sadar wisata, dan daya tarik wisata. Pada dasarnya Pengembangan wisata di Hot Water Boom membutuhkan peranan masyarakat secara aktif seperti pemahaman tentang strategi yang dilakukan 
Meisi Kurniasari, Rahmadani Yusran|Peningkatan Peranan Sosial Masyarakat dalam Pengembangan Wisata Hot Water Boom Sapan Maluluang di Nagari Pauh Duo Nan Batigo Kecamatan Pauh Duo Kabupaten Solok-Selatan

serta dukungan yang dilakukan dalam pengembangan seperti ikut serta dalam proses perencanaan, proses pembangunan dan lain sebagainya. Tanpa peranan aktif dari masyarakat pengembangan tidak akan berjalan dengan optimal.

\section{TINJAUAN PUSTAKA}

\section{Konsep peranan sosial masyarakat}

Peranan sosial masyarakat ialah tindakan atau upaya seseorang dengan cara yang dilakukan melalui pikiran dalam mengerjakan hak dan tanggung jawabnya sesuai dengan jabatan yang dimiliki untuk meningkatkan kesejahteraan masyarakat. Misalnya, dalam mengembangkan pariwisata pada dasarnya terdiri dari pemerintah, masyarakat, dan swasta. Karena setelah pemerintah mengeluarkan keputusan mengenai pengembangan pariwisata yang sesuai dengan aturan tertentu. Selanjutnya, pihak swasta yang menyediakan jasa pelayanan untuk mengembangkan wisata tersebut. Maka tugas masyarakat merupakan pemahaman atau kesadaran tentang pentingnya wisata yang menumbuh kembangkan kreativitas yang melahirkan harapan-harapan baru yang dapat mengundang perhatian masyarakat. Dari harapan itulah seseorang kemudian akan bersikap, bertindak dan berusaha untuk mencapai kekuatan yang dimilikinya. Oleh karena itu peranan sosial masyarakat bisa diartikan dengan upaya atau tindakan yang telah direncanakan seseorang yang mempunyai kedudukan tertentu dalam masyarakat. Oleh karena itu, peranan sosial bisa didefinisikan sebagai upaya serta tindakan yang dilakukan masyarakat dalam pengembangan pariwisata yang tujuannya untuk meningkatkan kesejahteraan masyarakat.

Secara konseptual Lothar Gundling (1980) mengemukakan beberapa peranan sosial masyarakat sebagai berikut: Pertama, memberi informasi kepada pemerintah. Hal ini memberikan dan menambah pengetahuan khusus mengenai berbagai kegiatan aktivitas-aktivitas lingkungan, lebih jauh pemerintah dapat mengetahui adanya berbagai kepentingan yang terkait dalam suatu kegiatan sehingga outputnya lebih bermutu. Masukan dari masyarakat akan lebih menambah pengetahuan khusus mengenai sesuatu masalah. Pengetahuan khusus tambahan tentang masalah-masalah yang timbul itu mungkin dapat menambah dan meningkatkan mutu keputusan yang akan diambil, sehingga peranan sosial masyarakat dapat meningkatkan tindakan pemerintah dan lembaga-lembaganya. Pemerintah juga bisa mengetahui adanya berbagai kepentingan yang terkena tindakan dan perlu diperhatikan. Maka dari itu peranan sosial masyarakat sangatlah penting dalam rangka member informasi kepada pemerintah mengenai masalahmasalah dan konsekuensi yang timbul dari tindakan yang diambil pemerintah. Kedua, meningkatkan kesediaan masyarakat untuk menerima keputusan. Setiap warga masyarakat yang memperoleh kesempatan berperan serta dalam pengambilan keputusan akan cenderung untuk memperhatikan kesediaanya untuk menerima dan menyesuaikan diri dengan keputusan tersebut, dan akan mengurangi kemungkinan timbulnya pertentangan. Semua keputusan tidak akan menyelesaikan semua kepentingan, golongan, dan masyarakat, akan tetapi respons masyarakat dalam menerima keputusan pemerintah dapat di tingkatkan. Ketiga, mendemokrasikan pengambilan keputusan. Ada pendapat yang menyatakan bahwa dalam pemerintah dengan system perwakilan hak-hak untuk melaksanakan kekuasaan ada pada wakil-wakil rakyat yang dipilih oleh rakyat, dengan demikian tidak ada keharusan peran sosial masyarakat karena wakil rakyat lah yang bertindak untuk kepentingan masyarakat.

Adapun unsur-unsur utama peran sosial masyarakat, terdiri atas; 1) Tersedianya suatu kesempatan yang diorganisasikan bagi masyarakat untuk mengemukakan 
Meisi Kurniasari, Rahmadani Yusran/Peningkatan Peranan Sosial Masyarakat dalam Pengembangan Wisata Hot Water Boom Sapan Maluluang di Nagari Pauh Duo Nan Batigo Kecamatan Pauh Duo Kabupaten Solok-Selatan

pendapat dan pemikirannya terhadap kebijakan pemerintah; 2) Dengan adanya kesempatan bagi masyarakat untuk melakukan diskusi dengan pemerintah dan perencana; 3) Dalam batas-batas yang wajar diharapkan bahwa hasil diskusi tersebut dapat mempengaruhi pengembilan keputusan.

Pitana dan Gayatri (2005), mengemukakan pemerintah daerah memilikiperan untuk mengembangkan potensi pariwisata daerahnya sebagai: a) Motivator, dalam pengembangan pariwisata, peran pemerintah daerah sebagai motivator diperlukan agar geliat usaha pariwisata terus berjalan. Investor, masyarakat, serta pengusaha di bidang pariwisata merupakan sasaran utama yang perlu untuk terus diberikan motivasi agar perkembangan pariwisata dapat berjalan dengan baik; b)Fasilitator, sebagai fasilitator pengembangan potensi pariwisata peran pemerintah adalah menyediakan segala fasilitas yang mendukung segala program yang diadakan oleh pemerintah. Adapun pada prakteknnya pemerintah bisa mengadakan kerja sama dengan berbagai pihak, baik itu swasta maupun masyarakat; c) Dinamisator, dalam pilar good governance, agar dapat berlangsung pembangunan yang ideal, maka pemerintah, swasta dan masyarakat harus dapat bersinergi dengan baik. Pemerintah daerah sebagai salah satu stakeholder pembangunan pariwisata memiliki peran untuk mensinergiskan ketiga pihak tersebut, agar diantaranya tercipta suatu simbiosis mutualisme demi perkembangan pariwisata.

\section{Konsep pengembangan pariwisata}

Berdasarkan Undang-undang No.10 Th 2009. Pada bab 1 pasal 1 Tentang Kepariwisataan adalah keseluruhan kegiatan yang terkait dengan pariwisata dan bersifat multidimensi serta multidisiplin yang muncul sebagai wujud kebutuhan setiap orang dan Negara serta interaksi antara pengunjung, masyarakat sekitar, pemerintah, pemerintah daerah, dan pengusaha. Daerah tujuan pariwisata atau destinasi pariwisata merupakan kawasan geografis yang berada dalam satu wilayah administrative diantaranya terdapat daya tarik wisata, fasilitas pariwisata, fasilitas umum, aksesibilitas, dan masyarakat yang terkait dan melengkapi dalam terwujudnya kepariwisataan. Kawasan strategis pariwisata merupakan kawasan yang memiliki potensi untuk pengembangan pariwisata mempunyai pengaruh penting dalam aspek tertentu diantaranya pemberdayaan sumber daya alam, sosial dan budaya, daya dukung lingkungan hidup pertahanan dan keamanan, dan pertumbuhan ekonomi.

\section{Konsep masyarakat sadar wisata}

Masyarakat sadar wisata adalah pemahaman yang berkaitan dengan pengembangan pariwisata. lebih jauh lagi juga menyangkut posisi, misi dan peran melalui pembangunan Negara dan bangsa ini, dalam mengembangkan wisata pasti terdapat beberapa harapan dan masalah yang berkaitan dengan kepentingan pengunjung. Kepentingan tersebut termasuk kepentingan umum, bangsa, dan Negara. Masyarakat sadar wisata adalah masyarakat yang mengetahui apa yang sedang dikerjakan dan masalah-masalah yang dihadapi untuk membangun dunia wisata nasional. Melalui kesadaran dari masyarakat maka terdapat pemahaman dalam berbagai pihak, yang pada akhirnya mendorong masyarakat untuk mau berperan serta dalam pembangunan wisata. selanjutnya dengan adanya pemahaman tersebut maka masyarakat akan memperlancar tugas pekerjaan masingmasing serta bisa membina interaksi yang positif dalam pembangunan secara keseluruhan.

Melalui kesadaran masyarakat, pembangunan wisata melibatkan semua masyarakat, mulai dari kalangan paling atas 
Meisi Kurniasari, Rahmadani Yusran|Peningkatan Peranan Sosial Masyarakat dalam Pengembangan Wisata Hot Water Boom Sapan Maluluang di Nagari Pauh Duo Nan Batigo Kecamatan Pauh Duo Kabupaten Solok-Selatan

samping lapisan paling bawah, serta kalangan pemerintah, swasta dan masyarakat biasa. Semua itu diharapkan untuk ikut membantu dan menunjang usaha pembangunan wisata. masyarakat akan berusaha untuk membantu apabila mereka mengetahui apa yang perlu mereka lakukan dan mengapa mereka harus melakukannya. Mereka akan tertarik untuk ikut serta dalam pembangunan wisata apabila mereka sudah memahami dengan adanya bantuan dari masyarakat akan membawa dampak yang positif. Namun pada kenyataannya yang terjadi sampai sekarang adalah belum seperti yang diharapkan. Tingkat pemahaman dan kesadaran wisata masyarakat secara umum masih perlu ditingkatkan. Kadangkala dalam melayani keperluan wisatawan yang mengunjungi suatu daerah tujuan wisata pun baik oknum petugas pemerintahan, karyawan industry pariwisata maupun masyarakat belum menunjukkan sikap dan tindakan selayaknya tuan rumah.

\section{Konsep pengembangan pariwisata}

Menurut Wahyudi (2017), pengembangan pariwisata merupakan suatu proses yang dinamis dan berkelanjutan menuju ketataran nilai yang lebih tinggi dengan cara melakukan penyesuaian dan koreksi berdasarkan pada hasil monitoring dan evaluasi serta umpan balik implementasi rencana sebelumnya yang merupakan dasar kebijakan dan misi yang harus dikembangkan. Pengembangan pariwisata tidak bisa berdiri sendiri, malah sebaliknya terkait erat dalam perencanaan pembangunan yang secara inter sektoral dan inter regional. Indonesia adalah Negara yang sedang berkembang dalam tahap pembangunan, berusaha membangun industry pariwisata sebagai salah satu upaya untuk mencapai neraca perdagangan luar negeri yang seimbang. Pengembangan pariwisata tidak hanya untuk menambah devisa Negara maupun pendapatan pemerintah daerah, akan tetapi juga diharapkan dapat memperluas kesempatan berusaha disamping memberikan lapangan pekerjaan baru untuk mengurangi pengangguran. Pariwisata dapat menaikkan tarif hidup masyarakat yang tinggal dikawasan tujuan wisata tersebut melalui keuntungan secara ekonomi, dengan cara mengembangkan fasilitas yang mendukung dan menyediakan fasilitas rekreasi, wisatawan dan penduduk setempat saling menguntungkan. Pengembangan daerah wisata hendaknya memperlihatkan tingkatnya budaya, sejarah den ekonomi dari tujuan wisata. selain itu, pengembangan pariwisata mempunyai tujuan untuk memberikan keuntungan bagi komunitas tuan rumah maupun pengunjung. Dengan adanya pembangunan pariwisata diharapkan mampu meningkatkan taraf hidup masyarakat. pengembangan pariwisata diantaranya melalui pengunjung dan masyarakat sekitar dan penyediaan fasilitas infrastruktur yang nantinya akan saling menguntungkan. Pengembangan tersebut hendaknya sangat memperhatikan berbagai aspek, seperti: aspek budaya, sejarah dan ekonomi daerah tujuan wisata.

\section{METODE PENELITIAN}

Dalam penelitian ini, metode penelitian yang peneliti gunakan adalah penelitian kualitatif dengan metode deskriptif. Pemilihan dan penetapan informan dilakukan sesuai dengan karakteristik penelitian kualitatif yaitu dengan teknik purposive dan snowball sampling. Purposive sampling merupakan teknik penentuan informan dengan pertimbangan tertentu yakni orang yang dianggap paling tahu tentang apa yang diteliti oleh peneliti. Snowball sampling merupakan teknik penentuan sampel yang mula-mula jumlah informannya sedikit yakni dari satu atau dua orang hingga peneliti mencari tahu orang lain yang dapat melengkapi data yang peneliti teliti (dalam Sugiyono, 2009: 124). Informan dalam penelitian ini merupakan pihak-pihak yang memiliki informasi lengkap sesuai kebutuhan. Penelitian ini dilakukan dilakukan di Nagari Pauh Duo 
Meisi Kurniasari, Rahmadani Yusran|Peningkatan Peranan Sosial Masyarakat dalam Pengembangan Wisata Hot Water Boom Sapan Maluluang di Nagari Pauh Duo Nan Batigo Kecamatan Pauh Duo Kabupaten Solok-Selatan

Nan Batigo Kecamatan Pauh Duo Kabupaten Solok-Selatan. Informan dari penelitian ini adalah kasubbag umum dan kepegawaian, sekretaris Disparbud, wali nagari, ketua pemuda, tokoh masyarakat, petugas wisata HWB dan masyarakat yang berada disekitar objek wisata HWB.

Fokus penelitian ini yaitu: pertama, peranan sosial masyarakat ini penting dalam pengembangan pariwisata. kedua, bentuk-bentuk peranan sosial masyarakat dalam mendukung pengembangan wisata. ketiga, faktor yang mempengaruhi perlibatan peranan sosial masyarakat dalam pengembangan wisata.

Data yang digunakan adalah data primer dan sekunder yang diperoleh dari pengamatan dan observasi yang peneliti lakukan, berupa wawancara dan studi dokumentasi. Data ini diuji keabsahannya dengan teknik triangulasi. Karena data yang diperoleh merupakan data dari banyak sumber. Teknik triangulasi adalah pengumpulan data yang berbeda-beda melalui orang-orang-orang yang berbeda untuk mendapatkan data dari sumber yang sama.

\section{HASIL DAN PEMBAHASAN}

\section{Bentuk-Bentuk Peranan Sosial Masyarakat dalam Mendukung Pengembangan Wisata Hot Water Boom Sapan Maluluang Kabupaten Solok- Selatan}

a) Memberikan informasi kepada pemerintah

Mengacu kepada pendapat Lothar Gudling (1980), tentang perlibatan peranan sosial masyarakat, maka pada dasarnyaPerlibatan peranan sosial masyarakat dalam memberikan informasi terlihat dalam berbagai aktivitas diantaranya memberikan informasi terkait adanya pelayanan HWB, memberikan informasi tentang masalah adanya pelayanan yang belum maksimal yang diberikan oleh petugas objek wisata HWB. Selanjutnya memberikan informasi terkait dalam perbaikan fasilitas objek wisata HWB melalui berbagai pertemuan yang dilaksanakan oleh Pemerintah daerah.

Sesuai dengan pendapat Lothar Gundling yang menyatakan bahwa memberikan informasi kepada pemerintah dapat memberikan dan menambah pengetahuan mengenai berbagai kegiatan khususnya lingkungan. Melalui informasi tersebut pemerintah dapat mengetahui adanya berbagai kepentingan yang terkait dengan berbagai kegiatan sehingga outputnya lebih bermutu. Melalui informasi ini, Pemerintah dapat mengetahui adanya berbagai kepentingan yang terkait dengan berbagai aktivitas yang berkaitan dengan pengembangan objek wisata HWB.

b) Meningkatkan kesediaan masyarakat untuk menerima keputsan

Perlibatan peranan sosial masyarakat dalam bentuk kesediaan untuk menerima keputusan dalam pengembangan objek wisata HWB Sapan Maluluang diperlukan dalam kesediaan masyarakat dalam menerima keputusan. Diantaranya masyarakat bersedia melaksanakan keputusan yang sudah di musyawarahkan. Bentuk kesediaan masyarakat menerima keputusan yaitu dalam menjaga dan merawat objek wisata HWB dengan baik. Selanjutnya, masyarakat bersedia menerima sanksi atas kelalaian dalam menjalankan tugasnya. Tidak hanya itu, sanksi dalam bentuk melalaikan tugas juga berlaku bagi petugas HWB. Dan kesediaan masyarakat untuk menerima keputusan dalam pengembangan objek wisata HWB adalah bersedia membayar retribusi apabila berjualan di lokasi objek wisata HWB.

Sesuai dengan penelitian Agow (2017) dan Waani (2016) bahwa, meningkat kesediaan masyarakat dalam perlibatan peranan sosial masyarakat menerima keputusan sudah optimal dilakukan. Namun 
Meisi Kurniasari, Rahmadani Yusran/Peningkatan Peranan Sosial Masyarakat dalam Pengembangan Wisata Hot Water Boom Sapan Maluluang di Nagari Pauh Duo Nan Batigo Kecamatan Pauh Duo Kabupaten Solok-Selatan

demikian penelitian tersebut lebih membahas tentang aspek ekonomi untuk meningkatkan mutu hidup masyarakat saja, sementara peneliti lebih menekankan kepada pelibatan peranan sosial masyarakat dalam pengembangan objek wisata dalam bentuk meningkatkan kesediaan masyarakat menerima keputusan. Dengan demikian, kesediaan masyarakat untuk menerima keputusan dapat mengurangi timbulnya pertentangan.

c) Mendemokrasikan pengambilan keputusan

Perlibatan peranan sosial masyarakat dalam proses pendemokrasian pengambilan keputusan pada umunya dilaksanakan dalam bentuk musyawarah. Yang pertama musyawarah yang dilakukan menjelang lebaran wali nagari dan tokoh masyarakat dilibatkan dalam membuat keputusan tertentu. Kedua, dalam bentuk penertiban tarif parkir.

Sesuai dengan pendapat Lothar gundling bahwa, peranan sosial masyarakat sudah optimal dilaksanakan. Dari hasil penelitian menunjukkan bahwa pengambilan keputusan di objek wisata HWB dengan cara musyawarah atau merapatkan sesuatu yang dianggap penting dalam wisata tersebut yang melibatkan Pemerintah Daerah, Wali Nagari, Dan Masyarakat sekitar tentang keputusan apa yang akan diambil untuk wisata HWB untuk menuju langkah yang lebih baik dan mencapai tujuan yang diinginkan agar terciptanya kesejahteraan masyarakat. selain itu, masyarakat memiliki kesempatan untuk ikut terlibat dalam penyelenggaraan wisata. diantaranya, melalui penyampaian pendapat, saran, pertimbangan dalam pengambilan keputusan dalam proses perencanaan, pengawasan, dan pelaksanaan penyelenggara wisata. Selanjutnya, masyarakat harus ikut terlibat dalam proses pembangunan wisata HWB dan berkewajiban melestarikan daya tarik wisata, membantu terciptanya suasana tertib, bersih, aman, dan berkewajiban menjaga kelestarian objek wisata HWB.

\section{Peran Pemerintah Selama Ini dalam Melibatkan Peranan Sosial Masyarakat dalam Pengembangan Pariwisata di Kabupaten Solok-Selatan}

Pertama, memfasilitasi keterlibatan masyarakat dalam pengembangan objek wisata HWB dalam bentuk melibatkan masyarakat dalam perencanaan, membuka kesempatan pekerjaan bagi masyarakat yang tidak memiliki pekerjaan, peningkatan kualitas infrastruktur dan fasilitas umum, dan melakukan evaluasi dan pengawasan terhadap aktivitas wisata HWB.

Sesuai dengan penelitian Dewi, dkk (2013) dan Kurniawati (2018) bahwa peran pemerintah dalam perlibatan peranan sosial masyarakat sudah dilaksanakan tapi masih secara terbatas. Maksudnya, belum adanya keseriusan pemerintah secara keseluruhan kepada masyarakat dalam pengembangan objek wisata. Padahal dalam pengembangan objek wisata masyarakat sangat diperlukan dalam proses perencanaan, pengambilan keputusan, dan pengawasan. Namun demikian, Peran pemerintah hanya meningkatkan perekonomian masyarakat dalam pengembangan objek wisata. Selain itu peran pemerintah harus mampu mengembangkan potensi yang dimiliki di daerahnya, sehingga masyarakat lebih memahami pentingnya peranan sosial masyarakat dalam pengembangan objek wisata.

Kedua, mendorong peran aktif masyarakat dalam pengembangan objek wisata HWB, Dalam pengembangan pariwisata sudah dilibatkan tapi masih secara terbatas. Peran aktif masyarakat dalam mengambangkan objek wisata HWB terlihat dalam aspek memberikan kesempatan kepada masyarakat dalam membuat perencanaan, menjaga keamanan, menjaga kebersihan, memanfaatkan sumber daya alam secara berkelanjutan di wisata 
Meisi Kurniasari, Rahmadani Yusran/Peningkatan Peranan Sosial Masyarakat dalam Pengembangan Wisata Hot Water Boom Sapan Maluluang di Nagari Pauh Duo Nan Batigo Kecamatan Pauh Duo Kabupaten Solok-Selatan

HWB, dan meningkatkan pelindungan sumber daya alam. Disamping itu, Dengan adanya peran serta masyarakat sebagai pendukung kegiatan wisata, masyarakat menjadi memiliki peran yang sangat penting dalam usaha untuk memajukan objek wisata HWB, dimana masyarakat bertanggung jawab atas pemeliharaan, kegiatan, serta melestarikan wisata HWB tersebut. Dengan tercapainya hal ini maka kesadaran masyarakat akan semakin meningkat, sehingga akan mendorong pertumbuhan ekonomi rakyat dan pendapatan daerah akan semakin meningkat.

Faktor yang Mempengaruhi Perlibatan Peranan Sosial Masyarakat dalam Pengembangan Wisata HWB Sapan Maluluang Kabupaten Solok-Selatan

a) Faktor pendukung

Faktor pendukung perlibatan sosial masyakat dalam pengembangan objek wisata HWB terlihat dalam aspek masyarakat terlibat dalam membuat perencanaan objek wisata HWB, mendukung perlibatan peranan sosial masyarakat dalam pengembangan objek wisata adalah adanya kesediaan masyarakat dalam mendukung pelaksanaan peraturan yang dibuat dalam rangka pengembangan objek wisata HWB, mendukung perlibatan peranan sosial masyarakat dalam pengembangan objek wisata adalah adanya keterlibatan masyarakat dalam mendukung potensi daya tarik wisata HWB, dan mendukung perlibatan peranan sosial masyarakat dalam pengembangan objek wisata adalah adanya kenyamanan dan keamanan yang diberikan masyarakat kepada pengunjung. Selain itu, adanya potensi daya tarik wisata pada suatu daerah dapat menjadi salah satu pendorong untuk melakukan pengembangan wisata yang optimal dan sesuai tujuan yang diinginkan dan meningkatkan kesejahteraan masyarakat. Dengan potensi objek wisata yang menarik akan membuat pengunjung lebih tertarik untuk berkunjung ke objek wisata tersebut. Terutama daya tarik wisata yang ada di objek HWB yaitu air panas yang berasal dari sumber kaki bukit sapan maluluang yang bisa merebus telur karena uapnya yang begitu panas membuat wisatawan ingin berkunjung. Selain itu adanya keindahan alam yang ada disekitar objek wisata HWB seperti wahana anakanak, wahana dewasa, tempat terapi yang menjadi daya tarik objek wisata tersebut.

Sesuai dengan penelitian Haryani (2016) dan Sullianti (2018) bahwa, faktor pendukung perlibatan peranan sosial masyarakat adalah adanya daya tarik wisata untuk dikembangkan. Peranan sosial masyarakat dalam mendukung pengembangan objek wisata yaitu dengan cara menjaga dan merawat kelestarian daya tarik wisata sehingga kelestarian untuk menjaga dan merawat lebih ditingkatkan lagi untuk meningkatkan minat pengunjung untuk berkunjung ke objek wisata.

b) Faktor penghambat

Pengembangan wisata HWB Sapan Maluluang selain di dukung adanya faktor pendukung perlibatan peranan sosial masyarakat dalam pengembangannya, tentunya ada juga faktor penghambat perlibatan peranan sosial masyarakat dalam pengembangan objek wisata HWB. Faktor penghambat dalam melibatkan peranan sosial masyarakat adalah belum adanya keseriusan pemerintah dalam melibatkan masyarakat pada tahap perancanaan. Kemudian dalam melibatkan masyarakat seharusnya pemerintah memberikan pekerjaan tetap kepada masyarakat di sekitar objek wisata HWB, kurangnya inisiatif masyarakat setempat maupun petugas HWB dalam mengelola fasilitas wisata HWB, kurangnya petugas keamanan yag membuat wisatawan yang berkunjung agak merasa khawatir akan kendaraannya yang terlalu jauh dari objek wisata HWB. Selanjutnya kurangnya pengawasan yang kurang teratur membuat masyarakat sekitar 
Meisi Kurniasari, Rahmadani Yusran/Peningkatan Peranan Sosial Masyarakat dalam Pengembangan Wisata Hot Water Boom Sapan Maluluang di Nagari Pauh Duo Nan Batigo Kecamatan Pauh Duo Kabupaten Solok-Selatan

atau pengunjung wisata merasa resah atau tidak nyaman. Selanjutnya pemerintah lebih meningkatkan lagi keamanan dan pengawasan pengunjung agar kedepannya lebih meningkatkan pengunjung yang berkunjung. faktor penghambat lainnya adalah kurangnya fasilitas umum, adanya masyarakat yang berbuat curang seperti pencurian diesel dan adanya penggelapan karcis masuk yang tidak sesuai dengan harga yang telah ditetapkan. Selain itu, untuk meningkatkan perekonomian masyarakat sekitar juga lebih meningkatkan kesejahteraan masyarakatnya.

Sesuai dengan penelitian Nofriya (2016) dan Tanjung (2017) bahwa, faktor penghambat pelibatan peranan sosial masyarakat adalah kurangnya keikutsertaan anggota masyarakat dalam kegiatan pengelolaan dan adanya fasilitas tempat pembuangan sampah belum dimanfaatkan secara maksimal oleh wisatawan dan masyarakat setempat. Dengan demikian, dalam mengatasi masalah-masalah yang terdapat dalam pengembangan objek wisata seharusnya pemerintah lebih memberikan pemahaman atau pelatihan kepada masyarakatnya untuk lebih bertanggung jawab dalam pengembangan wisata disekitar daerahnya dan dapat meningkatkan pendapatan masyarakat. Selain itu, juga dapat menambah peningkatan pengunjung yang akan berkunjung ke objek wisata tersebut.

\section{PENUTUP}

Berdasarkan hasil penelitian, dapat disimpulkan bahwa peranan sosial masyarakat dalam pengembangan objek wisata HWB masih kurang optimal, perlibatan peranan sosial masyarakat dalam mengembangkan objek wisata HWB terkendala kesempatan masyarakat untuk berperan serta yang dilakukan pemerintah. Kesempatan yang dimiliki masyarakat oleh masyarakat untuk berperan masih secara terbatas. Adapun kemauan dan kemampuan masyarakat untuk terlibat dalam pengembangan objek wisata HWB terbilang cukup baik. Walaupun masih ada beberapa faktor penghambat masyarakat untuk terlibat seutuhnya dalam pengembangan objek wisata masih belum seutuhnya atau secara terbatas.

Berdasarkan kesimpulan tersebut maka saran yang peneliti sampaikan yaitu Pemerintah Kabupaten Solok Selatan teruma di Nagari Pauh Duo Nan Batigo Kecamatan Pauh Duo seharusnya memberikan kesempatan yang lebih besar kepada masyarakatnya untuk terlibat dalam mengembangkan objek wisata HWB mulai dari pengambilan keputusan, pelaksanaan kegiatan, evaluasi, dan pemanfaatan hasil pembangunan. Untuk meningkatkan perlibatan masyarakat dalam pengembangan objek wisata HWB seharusnya pemerintah harus bisa melakukan pelatihan untuk meningkatkan perlibatan masyarakat dalam meningkatkan kesejahteraan masyarakat.

\section{DAFTAR KEPUSTAKAAN}

Adil Mubarak. (2014). Peran Ormas dalam Menjalankan Fungsi Pemerintah Bidang Pemberdayaan. Seminar Nasional UT 2014, 23 Oktober 2014, Universitas Terbuka Convention Center (UTCC). http://repository.ut.ac.id/5102/

Bakaruddin. 2008. Perkembangan dan Permasalahan kepariwisataan. Padang:UNP Press.

2009. Perkembangan dan Permasalahan Kepariwisataan. Padang:UNP Press.

Gundling, Lothar. 1980. Public Participation in Environmental Decision Making in Trends in Environmental Policy and Law. IUCN. Gland, Switzerland. 
Meisi Kurniasari, Rahmadani Yusran/Peningkatan Peranan Sosial Masyarakat dalam Pengembangan Wisata Hot Water Boom Sapan Maluluang di Nagari Pauh Duo Nan Batigo Kecamatan Pauh Duo Kabupaten Solok-Selatan

Soekanto, Soerjono. 2014. Sosiologi Suatu Pengantar. Jakarta: Rajawali Pers.

Undang-undang Republik Indonesia No. 10 Tahun 2009 Tentang Kepariwisataan.

http://www.kemenpar.go.id/userfiles/file/4 636_1364UUTentangkepariwisataann et1.pdf

Peraturan Daerah Kabupaten SolokSelatan Nomor 8 Tahun 2012 Tentang Rencana Tata Ruang Wilayah Daerah Kabupaten Solok-Selatan Tahun 20122032
Simamora, Rotua Kristin dan Sinaga, Rudi Salam. 2016. Peran Pemerintah Daerah dalam Pengembangan Pariwisata Alam dan Budaya di Kabupaten Tapanuli Utara. Jurnal Ilmu Pemerintahan dan Sosial Politik UMA. Vol. 4 No.1

Yusran, Rahmadani. 2007. Evaluasi Dampak Kebijakan Pemekaran Daerah Di Indonesia: Studi Daerah Pemekaran Kabupaten Solok-Selatan. Jurnal Demokrasi. Vol. VI No. 2.ISSN: 14121522 